\title{
Synthesis of 2-(aminomethyl)aziridines and their microwave- assisted ring opening to 1,2,3-triaminopropanes as novel antimalarial pharmacophores
}

\author{
Matthias D’hooghe, ${ }^{1, *}$ Sara Kenis, ${ }^{1}$ Karel Vervisch, ${ }^{1}$ Carmen Lategan, ${ }^{2}$ Peter J. Smith, ${ }^{2}$ \\ Kelly Chibale, ${ }^{3}$ and Norbert De Kimpe ${ }^{1, *}$ \\ ${ }^{l}$ Department of Sustainable Organic Chemistry and Technology, Faculty of Bioscience Engineering, \\ Ghent University, Coupure Links 653, B-9000 Ghent, Belgium \\ ${ }^{2}$ Medical School, University of Cape Town, K45, OMB, Groote Schuur Hospital, Observatory, 7925, \\ South Africa \\ ${ }^{3}$ Department of Chemistry and Institute of Infectious Disease \& Molecular Medicine, University of \\ Cape Town, Rondebosch 7701, South Africa
}

\begin{abstract}
A variety of 2-(aminomethyl)aziridines was prepared and converted into the corresponding 1,2,3triaminopropanes through a novel, microwave-assisted and regioselective ring opening by diethylamine in acetonitrile. Antiplasmodial assays revealed antimalarial activity for 2-[(1,2,4-triazol1-yl)methyl]aziridines and 2-(N,N-diethylaminomethyl)aziridines, as well as for the corresponding 1(diethylamino)propanes obtained through ring opening, pointing to the relevance of both the 2(aminomethyl)aziridine and the 1,2,3-triaminopropane unit as novel antimalarial pharmacophores.
\end{abstract}

Keywords: aziridines; aziridinium salts; ring opening; triaminopropanes; antimalarial agents

\section{Introduction}

With 247 million clinical cases and nearly one million deaths in 2008, mostly among African children, malaria remains a major issue in health control [1]. Quinoline containing compounds, such as the potent and inexpensive chloroquine (CQ) $[2,3,4]$ have a long tradition in the treatment of malaria, and systematic modification has led to a variety of antimalarial drugs with diverse substitutions around the quinoline ring [5,6]. However, the spread of chloroquine-resistant Plasmodium falciparum strains has dashed hopes of global malaria eradication and has complicated the clinical management of malaria in endemic areas. Consequently, many efforts are devoted to the design and synthesis of novel and structurally

\footnotetext{
*matthias.dhooghe@UGent.be

*norbert.dekimpe@UGent.be
} 
diverse compounds with potential antimalarial activity. Recently, the $\beta$-amino alcohol moiety has been introduced as a promising antimalarial pharmacophore, and the synthesis of a number of novel aminopropanols with significant antimalarial activity has revealed the medicinal importance of this class of glycerol analogues $[7,8,9]$. Their aza-derivatives, i.e. 1,2,3-triaminopropanes, however, have not been the subject of antimalarial screening up to now.

In this paper, the preparation and biological evaluation of novel 2-(aminomethyl)aziridines and 1,2,3-triaminopropanes is described as potential new lead compounds within the framework of malaria management and treatment.

The aziridine moiety represents one of the most valuable three-membered ring systems in organic chemistry $[10,11,12,13,14,15,16,17]$, and the regiocontrolled ring opening of $C$ substituted aziridines constitutes a powerful approach towards the preparation of a large variety of nitrogen-containing target compounds. In contrast to their activated counterparts, non-activated aziridines have been evaluated to a limited extent up to now, both from a synthetic and a pharmacological point of view. Due to the presence of an electron-donating substituent at nitrogen, the latter aziridines have to be activated toward aziridinium ion intermediates prior to ring opening [18,19,20,21,22,23,24,25,26,27,28,29,30,31]. Within the present work, the scarcely studied subclass of non-activated 1-alkyl-2(aminomethyl)aziridines [32,33,34,35,36,37,38,39] was employed as a source of substrates for the development of a novel entry toward the biologically relevant 1,2,3-triaminopropane unit through a highly regioselective and microwave-assisted ring opening by diethylamine in acetonitrile.

\section{Results and discussion - Synthesis}

Given the recently disclosed antimalarial properties of aminopropanols [7,8,9], and taking structure-activity relationship studies with regard to chloroquine into account [40], the elaboration of a 1,2,3-triaminopropane unit substituted with an aryl group, a $N, N$ diethylamino moiety and an azaheteroaromatic nucleus was envisaged as a potential novel antimalarial pharmacophore. From a retrosynthetic point of view, 2-(aminomethyl)aziridines can be regarded as suitable precursors for the preparation of 1,2,3-triaminopropanes through ring opening by amines. Thus, the synthesis of properly substituted aziridines, bearing an azaheteroaromatic group in their side chain, was proposed, which then could serve as eligible substrates for the preparation of the desired targets through aziridine ring opening by a nucleophilic amine. 
At first, a variety of 2-(aminomethyl)aziridines 2 was prepared via coupling of different nitrogen nucleophiles with 2-(bromomethyl)aziridines 1 [41,42,43], employing the electrophilicity of the latter as a convenient handle for their connection to other moieties [33]. In order to introduce structural diversity within the amino side chain, aziridines 1 were connected to different classes of aromatic azaheterocycles such as adenine [44], thymine and 1,2,4-triazole en route to the corresponding 2-(aminomethyl)aziridines $\mathbf{2 a - h}$ (Scheme 1, Table 1). In addition, also diethylamine was used for the preparation of $2-(\mathrm{N}, \mathrm{N}-$ diethylaminomethyl)aziridines $\mathbf{2} \mathbf{i}-\mathbf{k}$ in order to evaluate the difference between the presence of an aromatic azaheterocyclic moiety and a simple acyclic amino group in 1,2,3triaminopropanes with regard to their biological activity.

The synthesis of 2-[(6-aminopurin-9-yl)methyl]aziridines 2a-c was accomplished upon treatment of 2-(bromomethyl)aziridines 1 with 1 equiv of adenine in DMF at $80{ }^{\circ} \mathrm{C}$ for 5 hours in the presence of 5 equiv of $\mathrm{K}_{2} \mathrm{CO}_{3}$ (Table 1, entries 1-3). Next to the desired N9substituted adenines 2a-c, isomeric $N 7$-alkylation products were observed as well in minor amounts $(N 9 / N 7 \sim 3 / 1)$, which is in accordance with literature data on the $N$-alkylation of adenine [45]. The premised adenine derivatives 2a-c were isolated in pure form through crystallization. In recent years, the synthesis of functionalized adenines has gained much interest due to the pronounced biological activities, such as antitumor and antiviral, associated to this class of compounds $[46,47,48]$. Besides purines, also pyrimidines are known to be of importance as lead compounds in medicinal chemistry $[48,49,50]$. In that respect, thymine was used as a nucleophile toward the preparation of 2-[(2,4-dioxo-5-methylpyrimidin-1yl)methyl]aziridines 2d,e upon treatment of 2-(bromomethyl)aziridines $\mathbf{1}$ with one equiv of thymine and one equiv of $\mathrm{NaH}$ in DMF at $80{ }^{\circ} \mathrm{C}$ for 3 hours (Table 1, entries 4-5). The former aziridines 2d,e were obtained in good crude yields, and were purified by crystallization from $\mathrm{CH}_{2} \mathrm{Cl}_{2} / \mathrm{Et}_{2} \mathrm{O}$ (4/1) in order to obtain analytically pure samples (the yields in Table 1 are yields obtained after purification).

Next to DNA bases, the 1,2,4-triazole moiety was introduced as an aziridine side chain through reaction of aziridines 1 with 5 equiv of 1,2,4-triazole [51] in $\mathrm{CH}_{3} \mathrm{CN}$ under reflux for $2.5 \mathrm{~d}$ in the presence of 4 equiv of $\mathrm{K}_{2} \mathrm{CO}_{3}$, affording the corresponding triazoles $\mathbf{2 f - h}$ in good yields (Table 1, entries 6-8) [33]. These long reaction times appeared to be necessary in order to drive the reaction to completion. Finally, a number of $2-(N, N-$ 
diethylaminomethyl)aziridines $\mathbf{2 i - k}$ were prepared in good yields using an excess (16 equiv) of diethylamine in methanol under reflux for one day (Table 1, entries 9-11).

Scheme 1. Synthesis of 2-(aminomethyl)aziridines 2 and their microwave-assisted conversion into 1,2,3-triaminopropanes $\mathbf{3}$
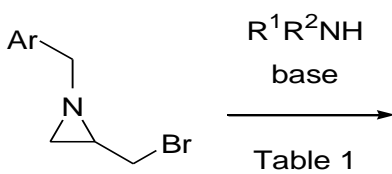

1

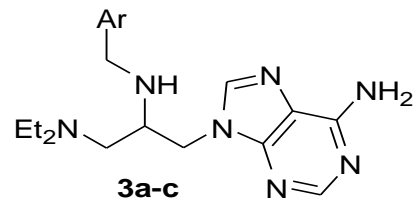

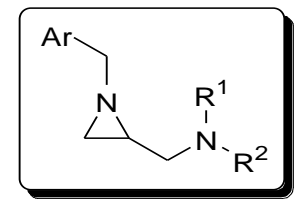

2a-k (26-90\%)

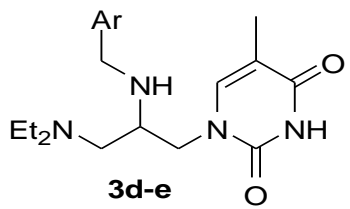

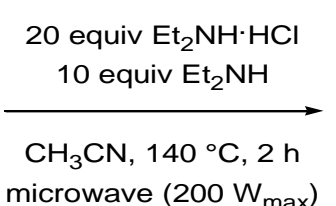

microwave $\left(200 \mathrm{~W}_{\max }\right)$

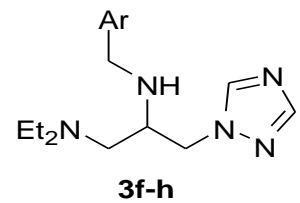

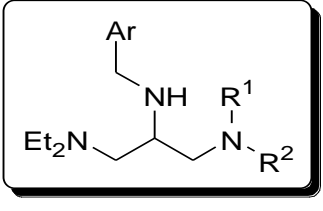

3a-k (13-65\%)<smiles></smiles>

Subsequently, 2-(aminomethyl)aziridines $\mathbf{2 a - k}$ were converted into novel 1,2,3triaminopropanes 3a-k bearing a diethylamino group through elaboration of the constrained aziridine moiety. The interest in this type of compounds stems from the known antimalarial activity of aminopropanols on the one hand and the relevance of a diethylamino unit in potent antimalarial agents (e.g. chloroquine) on the other hand. With the intention to introduce a diethylamino group, the ring opening of aziridines $\mathbf{2}$ by diethylamine was envisaged. Given the necessary activation of non-activated aziridines prior to ring opening, the use of diethylamine hydrochloride was contemplated. In this way, protonation of the aziridine ring provides a highly electrophilic aziridinium intermediate which is prone to nucleophilic ring opening. In order to drive the reaction to completion, and to avoid competition between chloride- and diethylamine-induced ring opening, a large excess of $\mathrm{Et}_{2} \mathrm{NH} \cdot \mathrm{HCl}$ (20 equiv) and an additional amount of diethylamine (10 equiv) was used. Nonetheless, only partial conversion $(<80 \%)$ of aziridines 2 was achieved after heating under reflux for 7 days in acetonitrile under the given reaction conditions. Fortunately, the poor reactivity of 2(aminomethyl)aziridines 2 with regard to the $\mathrm{Et}_{2} \mathrm{NH} \cdot \mathrm{HCl} / \mathrm{Et}_{2} \mathrm{NH}$ system under conventional heating was easily overcome through the application of microwave irradiation. Heating of the latter aziridines 2 at $140{ }^{\circ} \mathrm{C}\left(200 \mathrm{~W}_{\max }\right)$ in $\mathrm{CH}_{3} \mathrm{CN}$ resulted in full and selective conversion to the desired triaminopropanes $\mathbf{3}$ after 2 hours (Scheme 1), which were purified by 
crystallization or column chromatography $\left(\mathrm{Al}_{2} \mathrm{O}_{3}\right)$ in order to obtain analytically pure samples (13-65\% yield).

Table 1. Synthesis of 2-(aminomethyl)aziridines $2 \mathrm{a}-\mathrm{k}$

\begin{tabular}{|c|c|c|c|c|}
\hline Entry & $\mathbf{A r}$ & $\mathbf{R}^{1} \mathbf{R}^{2} \mathbf{N H}$ & Reaction conditions ${ }^{\mathrm{a}}$ & Product (yield $^{\mathrm{b}}$ ) \\
\hline$\overline{11}$ & $\mathrm{Ph}$ & Adenine & $\overline{\mathbf{A}}$ & 2a (31\%) \\
\hline 2 & $4-\mathrm{ClC}_{6} \mathrm{H}_{4}$ & Adenine & $\mathbf{A}$ & $\mathbf{2 b}(51 \%)$ \\
\hline 3 & $4-\mathrm{MeOC}_{6} \mathrm{H}_{4}$ & Adenine & $\mathbf{A}$ & $\mathbf{2 c}(32 \%)$ \\
\hline 4 & $4-\mathrm{ClC}_{6} \mathrm{H}_{4}$ & Thymine & $\mathbf{B}$ & 2d $(34 \%)$ \\
\hline 5 & $4-\mathrm{MeOC}_{6} \mathrm{H}_{4}$ & Thymine & B & $\mathbf{2 e}(26 \%)$ \\
\hline 6 & $\mathrm{Ph}$ & 1,2,4-triazole & $\mathbf{C}$ & $\mathbf{2 f}(90 \%)$ \\
\hline 7 & $4-\mathrm{ClC}_{6} \mathrm{H}_{4}$ & 1,2,4-triazole & $\mathbf{C}$ & $\mathbf{2 g}(63 \%)$ \\
\hline 8 & $4-\mathrm{MeOC}_{6} \mathrm{H}_{4}$ & 1,2,4-triazole & $\mathbf{C}$ & 2h $(54 \%)$ \\
\hline 9 & $\mathrm{Ph}$ & $\mathrm{Et}_{2} \mathrm{NH}$ & $\mathbf{D}$ & $\mathbf{2 i}(90 \%)$ \\
\hline 10 & $4-\mathrm{ClC}_{6} \mathrm{H}_{4}$ & $\mathrm{Et}_{2} \mathrm{NH}$ & D & $2 \mathbf{j}(63 \%)$ \\
\hline 11 & $4-\mathrm{MeOC}_{6} \mathrm{H}_{4}$ & $\mathrm{Et}_{2} \mathrm{NH}$ & D & $\mathbf{2 k}(64 \%)$ \\
\hline
\end{tabular}

${ }^{\mathrm{a}}$ Reaction conditions: $\mathbf{A}=1$ equiv adenine, 5 equiv $\mathrm{K}_{2} \mathrm{CO}_{3}$, DMF, $80{ }^{\circ} \mathrm{C}, 5 \mathrm{~h} ; \mathbf{B}=1$ equiv thymine, 1 equiv $\mathrm{NaH}$, DMF, $80{ }^{\circ} \mathrm{C}, 3 \mathrm{~h}$; $\mathbf{C}=5$ equiv 1,2,4-triazole, 4 equiv $\mathrm{K}_{2} \mathrm{CO}_{3}, \mathrm{CH}_{3} \mathrm{CN}, \Delta, 2.5 \mathrm{~d} ; \mathbf{D}=16$ equiv $\mathrm{Et}_{2} \mathrm{NH}, \mathrm{MeOH}, \Delta, 1 \mathrm{~d}$

${ }^{\mathrm{b}}$ Yield after purification by crystallization or column chromatography

For aziridines $\mathbf{2 a - h}$, bearing an aromatic azaheterocyclic side chain, the ring opening of intermediate aziridinium ions $\mathbf{4 a - h}$ proceeded with excellent regioselectivity through attack at the unhindered aziridinium carbon atom (Scheme 2). In the case of 2-(N,Ndiethylaminomethyl)aziridines $\mathbf{2} \mathbf{i}-\mathbf{k}$, however, a mixture of regioisomers ( $3 / 2 \mathbf{3 i - k} / \mathbf{6} \mathbf{i}-\mathbf{k})$ was obtained, with the major isomers 3i-k being formed through ring opening of the initially formed aziridinium salts $\mathbf{4 i - k}$ at the less hindered position (Scheme 2, pathway a). Due to the presence of a nucleophilic nitrogen atom in the diethylaminomethyl group, rearrangement of aziridinium salts $\mathbf{4 i - k}$ to the corresponding 1,1-diethylaziridinium intermediates $\mathbf{5}$ occurred as well. Then, ring opening by diethylamine at the unhindered aziridinium carbon atom took place, giving rise to the formation of 1-(arylmethyl)amino-2,3-bis(diethylamino)propanes 6 (Scheme 2, pathway b). Only the major isomers 3i-k were isolated in pure form through column chromatography on aluminium oxide.

The observed regioselectivity was confirmed through detailed spectroscopic analysis of triaminopropanes $\mathbf{3}$. In addition, the formation of symmetric compounds $\mathbf{3 i}-\mathbf{k}$ further 
corroborates the regiochemical ring opening of aziridinium salts 4 by diethylamine at the unsubstituted carbon atom.

Scheme 2. Regioselectivity in the ring opening of 2-(aminomethyl)aziridines 2 using $\mathrm{Et}_{2} \mathrm{NH} \cdot \mathrm{HCl} / \mathrm{Et}_{2} \mathrm{NH}$

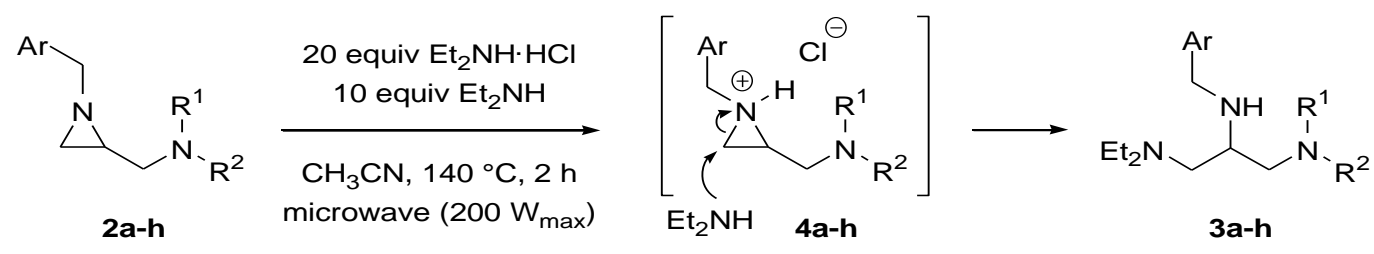

$\mathrm{R}^{1} \mathrm{R}^{2} \mathrm{NH}=$ adenine, thymine, 1,2,4-triazole

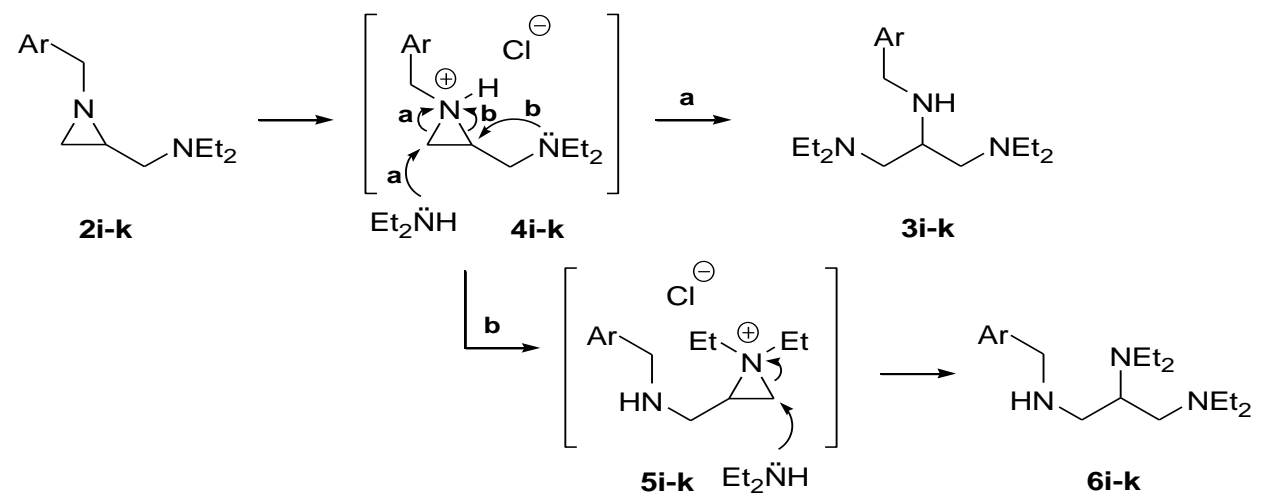

\section{Results and discussion - Biological evaluation}

Both classes of compounds, i.e. 2-(aminomethyl)aziridines 2 and 1,2,3-triaminopropanes 3, were screened for in vitro antiplasmodial activity. All samples were tested in triplicate on one occasion against a chloroquine sensitive (CQS) strain of P. falciparum (D10). Additionally, those samples showing promising antimalarial activity were tested in triplicate on one occasion against a chloroquine-resistant (CQR) strain of $P$. falciparum (Dd2) and screened for in vitro cytotoxicity against a mammalian cell-line, Chinese Hamster Ovarian (CHO), in triplicate on one occasion.

The test samples were prepared to a $2 \mathrm{mg} / \mathrm{mL}$ stock solution in $10 \%$ DMSO and sonicated to enhance solubility. The samples were tested as a suspension and stock solutions were stored at $-20^{\circ} \mathrm{C}$. Further dilutions were prepared on the day of the experiment.

\section{Antiplasmodial assay}

Continuous in vitro cultures of asexual erythrocyte stages of $P$. falciparum were maintained using a modified method of Trager and Jensen [52]. Quantitative assessment of 
antiplasmodial activity in vitro was determined via the parasite lactate dehydrogenase assay using a modified method described by Makler [53]. Chloroquine diphosphate (Sigma) (CQ) was used as the reference drug in all experiments. A full dose-response was performed for all compounds to determine the concentration inhibiting $50 \%$ of organism growth $\left(\mathrm{IC}_{50}\right.$-value).

\section{Cytotoxicity assay}

The MTT-assay [3-(4,5-dimethylthiazol-2-yl)-2,5-diphenyltetrazolium bromide-assay] is used as a colorimetric assay for cellular growth and survival, and compares well with other available assays [54,55]. The tetrazolium salt MTT was used to measure all growth and chemosensitivity. Emetine dihydrochloride (Sigma) was used as the reference drug in all experiments.

The results of the biological evaluation are summarized in Table 2 for 2(aminomethyl)aziridines $\mathbf{2}$ and in Table 3 for 1,2,3-triaminopropanes 3.

Although the aziridine moiety was initially not considered as a template for biological screening, both 2-[(1,2,4-triazol-1-yl)methyl]aziridine $\quad \mathbf{2 h} \quad$ and $\quad 2-(N, N$ diethylaminomethyl)aziridines $\mathbf{2 i - k}$ exhibited antiplasmodial activity against the CQS D10 strain of $P$. falciparum, with $\mathrm{IC}_{50}$-values between 15.3 and $4.2 \mu \mathrm{M}$ (Table 2). Moreover, aziridines $\mathbf{2 h}$ and $\mathbf{2 i - k}$ also showed antimalarial activity against the CQR Dd2 strain of $P$. falciparum ( $\mathrm{IC}_{50}$-values between 48.3 and $18.0 \mu \mathrm{M}$ ), and low (2i-k) or no (2h) cytotoxicity (Table 2).

With regard to the screening of 1,2,3-triaminopropanes $\mathbf{3}$, all representatives showed weak to potent antiplasmodial activities against the chloroquine sensitive (CQS) strain of $P$. falciparum, with $\mathrm{IC}_{50}$-values ranging from 214.1 to $2.0 \mu \mathrm{M}$ (Table 3 ), with some degree of cross resistance being displayed by $\mathbf{3 h}$. In particular, triazoles $\mathbf{3 g , h}$ and 1,3bis(diethylamino)propanes $\mathbf{3 j}$,k exhibited superior antimalarial activities with $\mathrm{IC}_{50}$-values between 8.4 and $2.0 \mu \mathrm{M}$. Furthermore, triazoles $\mathbf{3 f - h}$ and 1,3-bis(diethylamino)propanes 3i-k were tested against the chloroquine-resistant (CQR) strain of P. falciparum, again showing antiplasmodial activities. Interestingly, the in vitro cytotoxicity results showed that only compounds $3 \mathbf{j}$ and 3k have SI's of 9 and 24, respectively (Table 3), whereas all other compounds did not show cytotoxicity at the concentrations tested. 
Table 2. $\mathrm{IC}_{50}$-values of 2-(aminomethyl)aziridines 2 tested for in vitro antiplasmodial activity and cytotoxicity

\begin{tabular}{|c|c|c|c|c|c|c|c|}
\hline Compound & Ar & $\mathbf{R}^{1} \mathbf{R}^{2} \mathbf{N H}$ & $\begin{array}{c}\text { D10: } \text { IC }_{50} \\
(\mu \mathrm{M})\end{array}$ & $\begin{array}{c}\text { Dd2: } \text { IC }_{50} \\
(\mu M)\end{array}$ & $\begin{array}{c}\text { CHO: } \text { IC }_{50} \\
(\mu M)\end{array}$ & $\mathbf{R I}^{\mathrm{a}}$ & $\mathbf{S I}^{\mathrm{b}}$ \\
\hline $2 \mathbf{2 a}$ & $\mathrm{Ph}$ & & $>>350$ & ND & ND & ND & ND \\
\hline $2 b$ & $4-\mathrm{ClC}_{6} \mathrm{H}_{4}$ & & $>300$ & ND & $\mathrm{ND}$ & $\mathrm{ND}$ & ND \\
\hline $2 c$ & $4-\mathrm{MeOC}_{6} \mathrm{H}_{4}$ & & 266.76 & ND & ND & ND & ND \\
\hline $2 d$ & $4-\mathrm{ClC}_{6} \mathrm{H}_{4}$ & & 137.92 & $\mathrm{ND}$ & $\mathrm{ND}$ & $\mathrm{ND}$ & ND \\
\hline $2 e$ & $4-\mathrm{MeOC}_{6} \mathrm{H}_{4}$ & & 172.16 & ND & ND & ND & ND \\
\hline $2 f$ & $\mathrm{Ph}$ & HN-N & 80.74 & ND & ND & ND & ND \\
\hline $2 \mathrm{~g}$ & $4-\mathrm{ClC}_{6} \mathrm{H}_{4}$ & $\begin{array}{r}\langle\lambda\rangle \\
H N-N\end{array}$ & 125.97 & $\mathrm{ND}$ & $\mathrm{ND}$ & ND & ND \\
\hline $2 \mathrm{~h}$ & $4-\mathrm{MeOC}_{6} \mathrm{H}_{4}$ & $\begin{array}{l}\left\langle^{N}\right\rangle \\
H N-N\end{array}$ & $4.18(n=2)$ & 23.17 & $>400$ & 5.6 & ND \\
\hline $2 \mathbf{i}$ & $\mathrm{Ph}$ & $\mathrm{Et}_{2} \mathbf{N H}$ & 15.25 & 48.32 & 401.67 & 3.2 & 26.3 \\
\hline $2 \mathbf{j}$ & $4-\mathrm{ClC}_{6} \mathrm{H}_{4}$ & $\mathrm{Et}_{2} \mathrm{NH}$ & 6.49 & 23.74 & 247.33 & 3.7 & 38.1 \\
\hline $2 \mathbf{k}$ & $4-\mathrm{MeOC}_{6} \mathrm{H}_{4}$ & $\mathrm{Et}_{2} \mathrm{NH}$ & $8.54(n=2)$ & 18.04 & 193.15 & 2.1 & 22.6 \\
\hline CQ & & & $0.040(n=3)$ & 0.298 & & 7.5 & \\
\hline
\end{tabular}

\footnotetext{
${ }^{\mathrm{a}} \mathrm{RI}($ Resistance Index $)=\mathrm{IC}_{50} \mathrm{Dd} 2 / \mathrm{IC}_{50} \mathrm{D} 10$

${ }^{\mathrm{b}} \mathrm{SI}($ Selectivity Index $)=\mathrm{IC}_{50} \mathrm{CHO} / \mathrm{IC}_{50} \mathrm{D} 10$

$\mathrm{ND}=$ not determined

$\mathrm{n}=$ number of data sets averaged
} 
Table 3. $\mathrm{IC}_{50}$-values of 1,2,3-triaminopropanes 3 tested for in vitro antiplasmodial activity and cytotoxicity

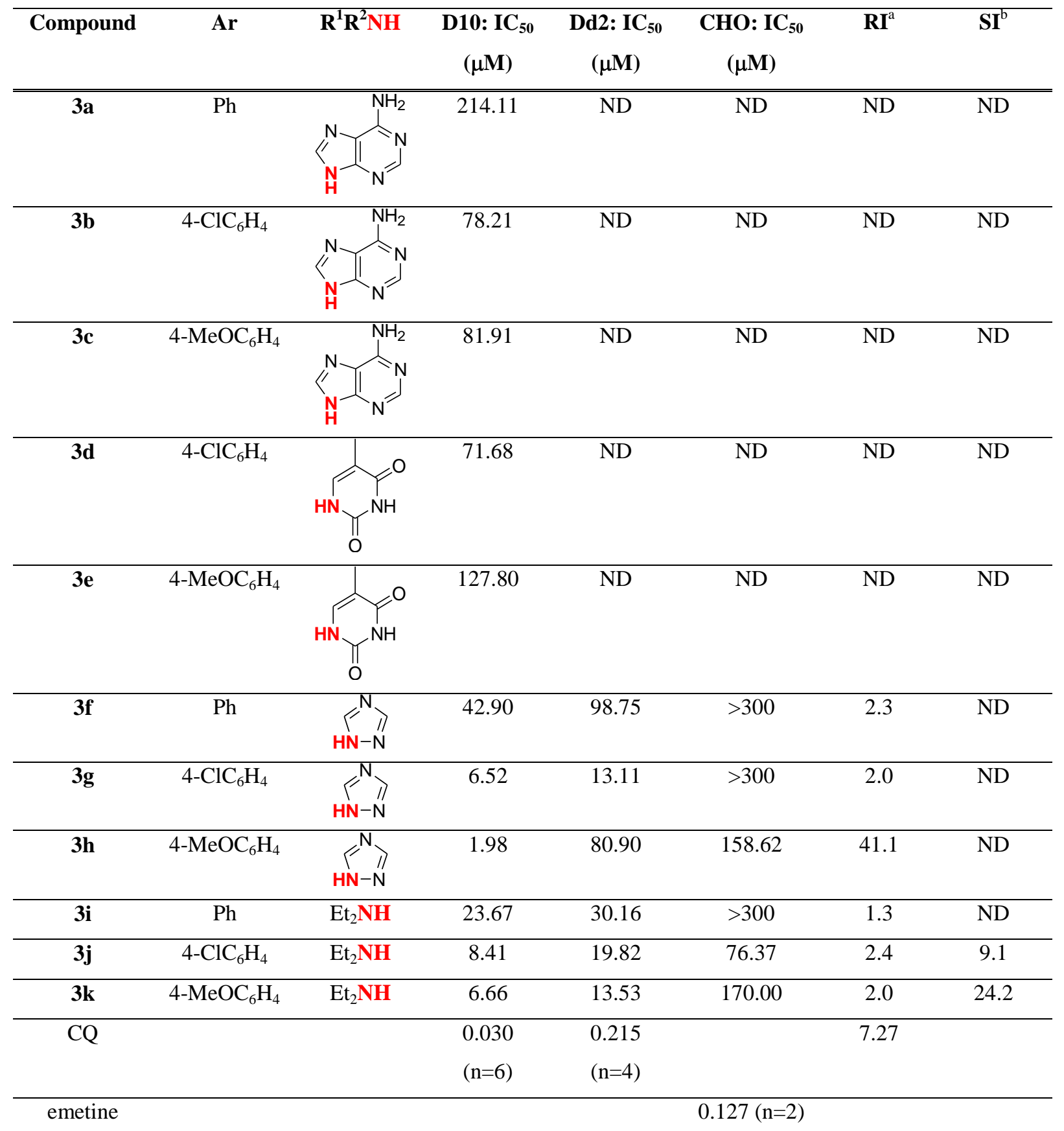

\footnotetext{
${ }^{\mathrm{a}} \mathrm{RI}\left(\right.$ Resistance Index) $=\mathrm{IC}_{50} \mathrm{Dd} 2 / \mathrm{IC}_{50} \mathrm{D} 10$

${ }^{\mathrm{b}} \mathrm{SI}($ Selectivity Index $)=\mathrm{IC}_{50} \mathrm{CHO} / \mathrm{IC}_{50} \mathrm{D} 10$

$\mathrm{ND}=$ not determined

$\mathrm{n}=$ number of data sets averaged
} 
It should be stressed that a number of 2-(aminomethyl)aziridines (e.g. 2h,j,k) and 1,2,3triaminopropanes (e.g. 3g,h,j,k), with $\mathrm{IC}_{50}$-values less than $10 \mu \mathrm{M}$, exhibited better antiplasmodial activities as compared to the previously reported class of aminopropanols [8], pointing to the promising potential of aziridines $\mathbf{2}$ and aminopropanes $\mathbf{3}$ within the context of the development of novel antimalarial agents. In that respect, structure/activity relationship studies should be performed as well in the future. It is noteworthy that these compounds were synthesized in racemic form, and it is conceivable that enantiomerically pure variants could deliver superior activities.

With regard to structure activity relationships, substituted propanes bearing a 1,2,4-triazole group at the 1-position, a 4-chloro- or 4-methoxybenzylamino substituent at the 2-position and a $N, N$-diethylamino moiety at the 3-position appear to be of particular interest in terms of their antimalarial activity. In addition, 1,3-bis(diethylamino)propanes bearing a 4-chloro- or 4-methoxybenzylamino substituent at the 2-position are also of importance in that respect.

In conclusion, a novel synthetic protocol was established for the straightforward conversion of a variety of 2-(aminomethyl)aziridines into 1,2,3-triaminopropanes through microwaveassisted regioselective ring opening by diethylamine using a combination of $\mathrm{Et}_{2} \mathrm{NH} \cdot \mathrm{HCl}$ and $\mathrm{Et}_{2} \mathrm{NH}$ in acetonitrile. Furthermore, both 2-(aminomethyl)aziridines and 1,2,3triaminopropanes were shown to be of biological relevance as potential antimalarial agents, in particular 2-[(1,2,4-triazol-1-yl)methyl]aziridines and 2-(N,N-diethylaminomethyl)aziridines as well as the corresponding 1-(diethylamino)propanes obtained through ring opening by diethylamine. Both the 2-(aminomethyl)aziridine and the 1,2,3-triaminopropane unit can thus be considered as novel antimalarial pharmacophores.

\section{Experimental section}

${ }^{1} \mathrm{H}$ NMR spectra were recorded at $300 \mathrm{MHz}$ (JEOL ECLIPSE+) with $\mathrm{CDCl}_{3}$ as solvent and tetramethylsilane as internal standard. ${ }^{13} \mathrm{C}$ NMR spectra were recorded at $75 \mathrm{MHz}$ (JEOL ECLIPSE+) with $\mathrm{CDCl}_{3}$ as solvent and tetramethylsilane as internal standard. Mass spectra were obtained with a mass spectrometer Agilent 1100, $70 \mathrm{eV}$. IR spectra were measured with a Spectrum One FT-IR spectrophotometer. Elemental analyses were performed with a PerkinElmer series II CHNS/O analyzer 2400. Dichloromethane was distilled over calcium hydride, while diethyl ether was dried over sodium benzophenone ketyl. Other solvents were 
used as received from the supplier. Melting points of crystalline compounds were measured with a Büchi 540 apparatus. The purity of all new compounds was assessed by means of NMR analysis (purity > 95\%).

Microwave reactions. All microwave reactions were performed in a CEM Focused Microwave ${ }^{T M}$ Synthesis System, Model Discover, with a selectable power output from 0 to 300 Watt. The reactions were performed in $10 \mathrm{~mL}$ thick walled Pyrex reaction vessels closed with a 'snap-on' septa cap and equipped with a small stirring bar. The temperature control uses a non-contact infrared sensor to measure the temperature on the bottom of the vessel and is used in a feedback loop with the on-board computer to regulate the temperature from 25 to $250{ }^{\circ} \mathrm{C}$ by adjusting the power output (1-Watt increments). The pressure control, IntelliVent ${ }^{T M}$ Pressure Control System, uses an indirect measurement of the pressure by sensing changes in the external deflection of the septa on the top of the sealed pressure vessel. Stirring is performed by a rotating magnetic plate located below the floor of microwave cavity. Cooling of the vessel after the reaction is performed by a stream of clean air onto the vessel which decreases the temperature of a $2 \mathrm{~mL}$ solution from $150{ }^{\circ} \mathrm{C}$ to $40{ }^{\circ} \mathrm{C}$ in less than 120 seconds. A ramp time of maximum 5 minutes is used during which the temperature increases from room temperature to the desired one. This temperature is maintained during the course of the reaction for the indicated time.

Synthesis of 2-(6-aminopurin-9-yl)methyl-1-(arylmethyl)aziridines (2a-c). General procedure: To a solution of 1-arylmethyl-2-(bromomethyl)aziridine 1 [41,42,43] (5 mmol) and adenine (5 mmol, 1 equiv) in dimethylformamide $(50 \mathrm{~mL})$ was added potassium carbonate ( $25 \mathrm{mmol}, 5$ equiv). After stirring for $5 \mathrm{~h}$ at $80{ }^{\circ} \mathrm{C}$, the solvent was removed under reduced pressure. The residue was poured into water $(25 \mathrm{~mL})$, extracted with $\mathrm{CHCl}_{3}(3 \times 25$ $\mathrm{mL})$ and washed with brine $(3 \times 25 \mathrm{~mL})$. The combined organic layers were dried over anhydrous magnesium sulfate. Filtration of the drying agent and removal of the solvent in vacuo afforded the crude products $\mathbf{2 a - c}$, which were purified by recrystallization.

2-(6-Aminopurin-9-yl)methyl-1-(phenylmethyl)aziridine (2a). Recrystallization from $\mathrm{CH}_{2} \mathrm{Cl}_{2} / \mathrm{Et}_{2} \mathrm{O}(4 / 1)$; yield $31 \% ; \mathrm{mp}=145.2{ }^{\circ} \mathrm{C} .{ }^{1} \mathrm{H}$ NMR $\left(300 \mathrm{MHz}, \mathrm{CDCl}_{3}\right): \delta 1.64(1 \mathrm{H}, \mathrm{d}, J$ $=6.6 \mathrm{~Hz}), 1.89(1 \mathrm{H}, \mathrm{d}, J=3.3 \mathrm{~Hz}), 2.07-2.13(1 \mathrm{H}, \mathrm{m}), 3.06$ and $3.63(2 \mathrm{H}, 2 \times \mathrm{d}, J=12.6 \mathrm{~Hz})$, $3.77(1 \mathrm{H}, \mathrm{d} \times \mathrm{d}, J=14.3,8.3 \mathrm{~Hz}), 4.50(1 \mathrm{H}, \mathrm{d} \times \mathrm{d}, J=14.3,3.9 \mathrm{~Hz}), 5.87$ (2H, br s), 7.09$7.21(4 \mathrm{H}, \mathrm{m}), 7.64$ and $8.34(2 \mathrm{H}, 2 \times \mathrm{s}) .{ }^{13} \mathrm{C} \mathrm{NMR}\left(75 \mathrm{MHz}, \mathrm{CDCl}_{3}\right): \delta 33.2,37.7,46.8,64.4$, $119.5,127.4,128.2,128.4,138.2,140.7,149.8,152.9,155.6 . \mathrm{IR}\left(\mathrm{ATR}, \mathrm{cm}^{-1}\right): v_{\mathrm{NH}}=3289$ and 
3103. MS (70 eV): $m / z(\%) 281\left(\mathrm{M}^{+}+1,100\right)$. Anal. calcd for $\mathrm{C}_{15} \mathrm{H}_{16} \mathrm{~N}_{6}: \mathrm{C} 64.27, \mathrm{H} 5.75, \mathrm{~N}$ 29.90; found: C 64.06, H 5.74, N 29.73.

2-(6-Aminopurin-9-yl)methyl-1-[(4-chlorophenyl)methyl]aziridine (2b). Recrystallization from $\mathrm{CH}_{2} \mathrm{Cl}_{2}$; yield $51 \%$; $\mathrm{mp}=167.6{ }^{\circ} \mathrm{C} .{ }^{1} \mathrm{H} \mathrm{NMR}\left(300 \mathrm{MHz}, \mathrm{CDCl}_{3}\right): \delta 1.64(1 \mathrm{H}, \mathrm{d}, J=6.1$ $\mathrm{Hz}), 1.91(1 \mathrm{H}, \mathrm{d}, J=3.3 \mathrm{~Hz}), 2.06-2.14(1 \mathrm{H}, \mathrm{m}), 2.91$ and $3.62(2 \mathrm{H}, 2 \times \mathrm{d}, J=12.9 \mathrm{~Hz}), 3.72$ $(1 \mathrm{H}, \mathrm{d} \times \mathrm{d}, J=14.3,8.3 \mathrm{~Hz}), 4.50(1 \mathrm{H}, \mathrm{d} \times \mathrm{d}, J=14.3,3.9 \mathrm{~Hz}), 5.72(2 \mathrm{H}, \mathrm{br} \mathrm{s}), 6.97-7.00$ and 7.08-7.11 (4H, $2 \times \mathrm{m}), 7.64$ and $8.34(2 \mathrm{H}, 2 \times \mathrm{s}) .{ }^{13} \mathrm{C} \mathrm{NMR}\left(75 \mathrm{MHz}, \mathrm{CDCl}_{3}\right): \delta 33.4,37.7$, $46.7,63.6,119.4,128.4,129.4,133.1,136.6,140.5,149.6,152.8,155.5$. IR $\left(\right.$ ATR, $\left.\mathrm{cm}^{-1}\right): v_{\mathrm{NH}}$ $=3311$ and 3119. MS (70 eV): $\mathrm{m} / z(\%): 315 / 7\left(\mathrm{M}^{+}+1,100\right)$. Anal. calcd for $\mathrm{C}_{15} \mathrm{H}_{15} \mathrm{ClN}_{6}: \mathrm{C}$ 57.24, H 4.80, N 26.70; found: C 57.04, H 4.97, N 26.85.

\section{2-(6-Aminopurin-9-yl)methyl-1-[(4-methoxyphenyl)methyl]aziridine}

(2c).

Recrystallization from $\mathrm{CH}_{2} \mathrm{Cl}_{2} / \mathrm{Et}_{2} \mathrm{O}$ (4/1); yield 32\%; mp = $181.1{ }^{\circ} \mathrm{C} .{ }^{1} \mathrm{H}$ NMR $(300 \mathrm{MHz}$, $\left.\mathrm{CDCl}_{3}\right): \delta 1.63(1 \mathrm{H}, \mathrm{d}, J=6.6 \mathrm{~Hz}), 1.87(1 \mathrm{H}, \mathrm{d}, J=3.3 \mathrm{~Hz}), 2.04-2.11(1 \mathrm{H}, \mathrm{m}), 2.93$ and 3.60 $(2 \mathrm{H}, 2 \times \mathrm{d}, J=12.6 \mathrm{~Hz}), 3.72(1 \mathrm{H}, \mathrm{d} \times \mathrm{d}, J=14.3,8.6 \mathrm{~Hz}), 3.78(3 \mathrm{H}, \mathrm{s}), 4.49(1 \mathrm{H}, \mathrm{d} \times \mathrm{d}, J=$ 14.3, 3.8 Hz), 5.52 (2H, br s), 6.65-6.70 (2H, m), 6.97-7.01 $(2 \mathrm{H}, \mathrm{m}), 7.65$ and $8.34(2 \mathrm{H}, 2 \times$ s). ${ }^{13} \mathrm{C}$ NMR $\left(75 \mathrm{MHz}, \mathrm{CDCl}_{3}\right): \delta 33.1,37.5,46.9,55.3,63.8,113.7,119.4,129.4,130.4$, 140.7, 149.7, 152.8, 155.6, 158.8. IR (ATR, $\left.\mathrm{cm}^{-1}\right): v_{\mathrm{NH}}=3310$ and 3121. MS $(70 \mathrm{eV}): \mathrm{m} / \mathrm{z}$ (\%): $311\left(\mathrm{M}^{+}+1,100\right)$. Anal. calcd for $\mathrm{C}_{16} \mathrm{H}_{18} \mathrm{~N}_{6} \mathrm{O}$ : C 61.92, H 5.85, N 27.08; found: $\mathrm{C}$ 61.45, H 5.97, N 26.91.

Synthesis of 1-arylmethyl-2-[(2,4-dioxo-5-methylpyrimidin-1-yl)methyl]aziridines (2d-e). General procedure: To a solution of 1-arylmethyl-2-(bromomethyl)aziridine 1 [41,42,43] (5 mmol) and thymine (5 mmol, 1 equiv) in dimethylformamide $(25 \mathrm{~mL})$ was added sodium hydride (60\% in mineral oil; $5 \mathrm{mmol}, 1$ equiv). After stirring for $3 \mathrm{~h}$ at $80{ }^{\circ} \mathrm{C}$, the solvent was removed under reduced pressure. The residue was poured into water $(10 \mathrm{~mL})$, extracted with chloroform $(3 \times 15 \mathrm{~mL})$ and washed with brine $(3 \times 15 \mathrm{~mL})$. The combined organic layers were dried over anhydrous magnesium sulfate. Filtration of the drying agent and removal of the solvent in vacuo afforded the crude products $2 \mathbf{2 d - e}$, which were purified by recrystallization from dichloromethane/ether (4/1).

1-(4-Chlorophenyl)methyl-2-[(2,4-dioxo-5-methylpyrimidin-1-yl)methyl]aziridine (2d). Recrystallization from $\mathrm{CH}_{2} \mathrm{Cl}_{2} / \mathrm{Et}_{2} \mathrm{O}$ (4/1); yield 34\%; mp = $149.4{ }^{\circ} \mathrm{C} .{ }^{1} \mathrm{H}$ NMR $(300 \mathrm{MHz}$, $\left.\mathrm{CDCl}_{3}\right): \delta 1.64(1 \mathrm{H}, \mathrm{d}, J=6.1 \mathrm{~Hz}), 1.74(3 \mathrm{H}, \mathrm{d}, J=1.1 \mathrm{~Hz}), 1.86(1 \mathrm{H}, \mathrm{d}, J=3.9 \mathrm{~Hz}), 2.00-$ $2.07(1 \mathrm{H}, \mathrm{m}), 2.79(1 \mathrm{H}, \mathrm{d}, J=12.1 \mathrm{~Hz}), 2.86(1 \mathrm{H}, \mathrm{d} \times \mathrm{d}, J=14.2,8.8 \mathrm{~Hz}), 3.87(1 \mathrm{H}, \mathrm{d}, J=$ $12.1 \mathrm{~Hz}), 4.35(1 \mathrm{H}, \mathrm{d} \times \mathrm{d}, J=14.2,3.1 \mathrm{~Hz}), 6.81(1 \mathrm{H}, \mathrm{d}, J=1.1 \mathrm{~Hz}), 7.16-7.21$ and 7.23-7.27 
$(4 \mathrm{H}, 2 \times \mathrm{m}), 9.42\left(1 \mathrm{H}\right.$, br s). ${ }^{13} \mathrm{C}$ NMR $\left(75 \mathrm{MHz}, \mathrm{CDCl}_{3}\right): \delta 12.2,32.4,37.5,51.1,63.5$, 110.0, 128.6, 130.0, 133.5, 136.9, 140.7, 151.0, 164.2. IR (ATR, $\left.\mathrm{cm}^{-1}\right): v_{\mathrm{CO}}=1698$ and 1660, $v_{\mathrm{NH}}=3192$. MS $(70 \mathrm{eV}): \mathrm{m} / z(\%): 306 / 8\left(\mathrm{M}^{+}+1,100\right)$. Anal. calcd for $\mathrm{C}_{15} \mathrm{H}_{16} \mathrm{ClN}_{3} \mathrm{O}_{2}: \mathrm{C}$ 58.92, H 5.27, N 13.74; found: C 59.31, H 5.46, N 13.46.

2-(2,4-Dioxo-5-methylpyrimidin-1-yl)methyl-1-[(4-methoxyphenyl)methyl]aziridine (2e). Recrystallization from $\mathrm{CH}_{2} \mathrm{Cl}_{2} / \mathrm{Et}_{2} \mathrm{O}$ (4/1); yield 26\%; mp $=167.7{ }^{\circ} \mathrm{C}$. ${ }^{1} \mathrm{H} \mathrm{NMR}(300 \mathrm{MHz}$, $\left.\mathrm{CDCl}_{3}\right): \delta 1.64(1 \mathrm{H}, \mathrm{d}, J=6.6 \mathrm{~Hz}), 1.67(3 \mathrm{H}, \mathrm{s}), 1.84(1 \mathrm{H}, \mathrm{d}, J=3.3 \mathrm{~Hz}), 1.99-2.05(1 \mathrm{H}, \mathrm{m})$, $2.60(1 \mathrm{H}, \mathrm{d}, J=12.1 \mathrm{~Hz}), 2.71(1 \mathrm{H}, \mathrm{d} \times \mathrm{d}, J=14.3,9.4 \mathrm{~Hz}), 3.79(3 \mathrm{H}, \mathrm{s}), 3.90(1 \mathrm{H}, \mathrm{d}, J=$ $12.1 \mathrm{~Hz}), 4.41(1 \mathrm{H}, \mathrm{d} \times \mathrm{d}, J=14.3,2.7 \mathrm{~Hz}), 6.73(1 \mathrm{H}, \mathrm{s}), 6.77-6.79(2 \mathrm{H}, \mathrm{m}), 7.11-7.14(2 \mathrm{H}$, m), $8.92\left(1 \mathrm{H}\right.$, br s). ${ }^{13} \mathrm{C} \mathrm{NMR}\left(75 \mathrm{MHz}, \mathrm{CDCl}_{3}\right): \delta 12.2,32.4,37.8,51.3,55.2,63.8,109.7$, $113.8,129.9,130.5,140.7,150.9,159.0,164.3$. IR $\left(\right.$ ATR, $\left.\mathrm{cm}^{-1}\right): v_{\mathrm{CO}}=1696$ and 1660, $v_{\mathrm{NH}}=$ 3189. MS (70 eV): $m / z(\%): 302\left(\mathrm{M}^{+}+1,100\right)$. Anal. calcd for $\mathrm{C}_{16} \mathrm{H}_{19} \mathrm{~N}_{3} \mathrm{O}_{3}: \mathrm{C} 63.77, \mathrm{H} 6.36$, N 13.94; found: C 63.46, H 5.99, N 13.46.

Synthesis of 1-arylmethyl-2-[(1,2,4-triazol-1-yl)methyl]aziridines (2f-h) [33]. General procedure: To a solution of 1-arylmethyl-2-(bromomethyl)aziridine $\mathbf{1}[41,42,43]$ (7.78 mmol) and 1,2,4-triazole (38.9 mmol, 5 equiv) in acetonitril $(100 \mathrm{~mL})$ was added potassium carbonate (31.12 mmol, 4 equiv), after which the resulting suspension was heated under reflux for 2 days. Afterwards, the solvent was removed under reduced pressure. The residue was poured into $75 \mathrm{~mL}$ of $1 \mathrm{M}$ sodium hydroxide solution and extracted with diethyl ether (3 x $30 \mathrm{~mL}$ ). The combined organic layers were dried over anhydrous potassium carbonate. Filtration of the drying agent and removal of the solvent in vacuo afforded the crude products 2f-h, which were purified by column chromatography on silica gel $\left(\mathrm{CHCl}_{3} / \mathrm{MeOH} 97 / 3\right)$.

1-(4-Methoxyphenyl)methyl-2-[(1,2,4-triazol-1-yl)methyl $]$ aziridine $\quad(2 \mathrm{~h}) . \quad R_{\mathrm{f}}=0.17$ $\left(\mathrm{CHCl}_{3} / \mathrm{MeOH} 97 / 3\right)$; yield 54\%. ${ }^{1} \mathrm{H} \mathrm{NMR}\left(300 \mathrm{MHz}, \mathrm{CDCl}_{3}\right): \delta 1.60(1 \mathrm{H}, \mathrm{d}, J=6.6 \mathrm{~Hz})$, $1.81(1 \mathrm{H}, \mathrm{d}, J=3.3 \mathrm{~Hz}), 1.99-2.06(1 \mathrm{H}, \mathrm{m}), 3.19$ and $3.44(2 \mathrm{H}, 2 \times \mathrm{d}, J=12.6 \mathrm{~Hz}), 3.78(3 \mathrm{H}$, s), $3.91(1 \mathrm{H}, \mathrm{d} \times \mathrm{d}, J=14.2,7.7 \mathrm{~Hz}), 4.30(1 \mathrm{H}, \mathrm{d} \times \mathrm{d}, J=14.2,4.2 \mathrm{~Hz}), 6.79-6.83(2 \mathrm{H}, \mathrm{m})$, 7.09-7.13 $(2 \mathrm{H}, \mathrm{m}), 7.86$ and $7.96(2 \mathrm{H}, 2 \times \mathrm{s}) .{ }^{13} \mathrm{C} \mathrm{NMR}\left(75 \mathrm{MHz}, \mathrm{CDCl}_{3}\right): \delta 32.6,37.5,52.6$, 55.2, 63.5, 113.9, 129.3, 130.4, 143.1, 151.6, 158.9. IR $\left(\right.$ ATR, $\left.\mathrm{cm}^{-1}\right): v_{\max }=2836,1612,1511$, 1273, 1244, 1176, 1139, 1031, 817, 751, 733, 679. MS (70 eV): $m / z(\%): 245\left(\mathrm{M}^{+}+1,100\right)$. Anal. calcd for $\mathrm{C}_{13} \mathrm{H}_{16} \mathrm{~N}_{4} \mathrm{O}$ : C 63.91, H 6.60, N 22.93; found: C 63.78, H 6.67, N 22.78.

Synthesis of 1-arylmethyl-2-(diethylaminomethyl)aziridines (2i-k). General procedure: A solution of 1-arylmethyl-2-(bromomethyl)aziridine $1 \quad[41,42,43] \quad(6.67 \quad \mathrm{mmol})$ and 
diethylamine (106.72 mmol, 16 equiv) in methanol $(100 \mathrm{~mL})$ was heated under reflux for 3 days. Afterwards, the reaction mixture was neutralized by means of a saturated sodium bicarbonate solution. The resulting suspension was poured into water $(70 \mathrm{~mL})$ and extracted with $\mathrm{CH}_{2} \mathrm{Cl}_{2}(3 \times 50 \mathrm{~mL})$. The combined organic layers were dried over anhydrous potassium carbonate. Filtration of the drying agent and removal of the solvent under reduced pressure afforded the crude products $\mathbf{2} \mathbf{i}-\mathbf{k}$, which were purified by column chromatography on silica gel.

2-(N,N-Diethylamino)methyl-1-(phenylmethyl)aziridine (2i). $R_{\mathrm{f}}=0.14\left(\mathrm{CHCl}_{3} / \mathrm{MeOH}\right.$ 95/5); yield 90\%. ${ }^{1} \mathrm{H}$ NMR (300 MHz, $\left.\mathrm{CDCl}_{3}\right): \delta 0.97(6 \mathrm{H}, \mathrm{t}, J=7.2 \mathrm{~Hz}), 1.40(1 \mathrm{H}, \mathrm{d}, J=6.6$ $\mathrm{Hz}), 1.60(1 \mathrm{H}, \mathrm{d}, J=3.3 \mathrm{~Hz}), 1.63-1.70(1 \mathrm{H}, \mathrm{m}), 2.38-2.62(6 \mathrm{H}, \mathrm{m}), 3.34$ and $3.46(2 \mathrm{H}, 2 \times \mathrm{d}$, $J=13.2 \mathrm{~Hz}), 7.20-7.39(5 \mathrm{H}, \mathrm{m}) .{ }^{13} \mathrm{C} \mathrm{NMR}\left(75 \mathrm{MHz}, \mathrm{CDCl}_{3}\right): \delta 11.6,32.7,38.0,47.0,56.2$, 64.7, 127.1, 128.4, 139.1. IR (ATR, $\left.\mathrm{cm}^{-1}\right): v_{\max }=2968,2799,2360,2341,1454,1348,1202$, 1069, 1028, 757, 731, 697. MS (70 eV): $m / z(\%): 219\left(\mathrm{M}^{+}+1,100\right)$. Anal. calcd for $\mathrm{C}_{14} \mathrm{H}_{22} \mathrm{~N}_{2}$ : C 77.01, H 10.16, N 12.83; found: C 76.79, H 10.03, N 12.77.

1-(4-Chlorophenyl)methyl-2-[(N,N-diethylamino)methyl]aziridine $\quad(\mathbf{2 j}) . \quad R_{\mathrm{f}}=0.22$ $\left(\mathrm{CHCl}_{3} / \mathrm{MeOH} 95 / 5\right)$; yield 63\%. ${ }^{1} \mathrm{H} \mathrm{NMR}\left(300 \mathrm{MHz}, \mathrm{CDCl}_{3}\right): \delta 0.99(6 \mathrm{H}, \mathrm{t}, J=7.2 \mathrm{~Hz})$, $1.42(1 \mathrm{H}, \mathrm{d}, J=6.6 \mathrm{~Hz}), 1.63(1 \mathrm{H}, \mathrm{d}, J=3.9 \mathrm{~Hz}), 1.66-1.71(1 \mathrm{H}, \mathrm{m}), 2.47-2.64(6 \mathrm{H}, \mathrm{m}), 3.33$ and $3.46(2 \mathrm{H}, 2 \times \mathrm{d}, J=13.5 \mathrm{~Hz}), 7.30(5 \mathrm{H}, \mathrm{s}) .{ }^{13} \mathrm{C} \mathrm{NMR}\left(75 \mathrm{MHz}, \mathrm{CDCl}_{3}\right): \delta 11.41,32.61$, $37.99,46.89,56.02,63.79,128.44,129.58,132.80,137.55$. IR $\left(\mathrm{ATR}, \mathrm{cm}^{-1}\right): v_{\max }=2970$, 1491, 1346, 1202, 1087, 1071, 1015, 806, 732. MS (70 eV): $m / z(\%): 253 / 5\left(\mathrm{M}^{+}+1,100\right)$. Anal. calcd for $\mathrm{C}_{14} \mathrm{H}_{21} \mathrm{ClN}_{2}$ : C 66.52, H 8.37, N 11.08; found: C 66.67, H 8.62, N 10.99.

2-(N,N-Diethylamino)methyl-1-[(4-methoxyphenyl)methyl]aziridine $\quad(2 \mathrm{k}) . \quad R_{\mathrm{f}}=0.07$ $\left(\mathrm{CHCl}_{3} / \mathrm{MeOH} 95 / 5\right)$; yield 64\%. ${ }^{1} \mathrm{H}$ NMR $\left(300 \mathrm{MHz}, \mathrm{CDCl}_{3}\right): \delta 0.99(6 \mathrm{H}, \mathrm{t}, J=7.2 \mathrm{~Hz}), 1.43$ $(1 \mathrm{H}, \mathrm{d}, J=6.1 \mathrm{~Hz}), 1.60(1 \mathrm{H}, \mathrm{d}, J=3.3 \mathrm{~Hz}), 1.65-1.70(1 \mathrm{H}, \mathrm{m}) ; 2.43-2.64(6 \mathrm{H}, \mathrm{m}), 3.33$ and $3.41(2 \mathrm{H}, 2 \times \mathrm{d}, J=13.2 \mathrm{~Hz}), 3.80(3 \mathrm{H}, \mathrm{s}), 6.84-6.88(2 \mathrm{H}, \mathrm{m}), 7.25-7.28(2 \mathrm{H}, \mathrm{m}) .{ }^{13} \mathrm{C} \mathrm{NMR}$ $\left(75 \mathrm{MHz}, \mathrm{CDCl}_{3}\right): \delta 11.5,32.5,37.7,46.9,55.3,56.1,64.1,113.8,129.4,131.2,158.8$. IR $\left(\mathrm{ATR}, \mathrm{cm}^{-1}\right): v_{\max }=2970,2933,1612,1512,1463,1300,1244,1174,1035,819,730 . \mathrm{MS}(70$ $\mathrm{eV}): m / z(\%): 249\left(\mathrm{M}^{+}+1,100\right)$. Anal. calcd for $\mathrm{C}_{15} \mathrm{H}_{24} \mathrm{~N}_{2} \mathrm{O}: \mathrm{C} 72.54, \mathrm{H} 9.74, \mathrm{~N}$ 11.28; found: C 72.43, H 9.84, N 11.16.

Synthesis of 1-(6-aminopurin-9-yl)-2-(arylmethyl)amino-3-diethylaminopropanes (3a-c). General procedure: In a $10 \mathrm{~mL}$ thick walled Pyrex reaction vessel, 2-(6-aminopurin-9yl)methyl-1-(arylmethyl)aziridine $\mathbf{2 a - c} \quad(0.89 \mathrm{mmol})$, diethylamine $(17.8 \mathrm{mmol})$ and diethylamine hydrochloride $(8.9 \mathrm{mmol})$ were dissolved in acetonitrile $(6 \mathrm{~mL})$. The mixture 
was heated to $140{ }^{\circ} \mathrm{C}$ for $2 \mathrm{~h}$ under microwave irradiation $\left(200 \mathrm{~W}_{\text {max }}\right)$. Afterwards, the reaction mixture was neutralized by means of a saturated sodium bicarbonate solution, poured into water $(15 \mathrm{~mL})$, extracted with diethyl ether $(3 \times 10 \mathrm{~mL})$ and washed with brine $(3 \times 10$ $\mathrm{mL}$ ). The combined organic layers were dried over anhydrous potassium carbonate. Filtration of the drying agent and removal of the solvent in vacuo afforded the crude products 3a-c, which were purified by recrystallization from $\mathrm{CH}_{2} \mathrm{Cl}_{2} / \mathrm{Et}_{2} \mathrm{O}(4 / 1)$.

\section{1-(6-Aminopurin-9-yl)-3-diethylamino-2-(phenylmethyl)aminopropane}

(3a).

Recrystallization from $\mathrm{CH}_{2} \mathrm{Cl}_{2} / \mathrm{Et}_{2} \mathrm{O}$ (4/1); yield 34\%; mp = $114.7{ }^{\circ} \mathrm{C} .{ }^{1} \mathrm{H}$ NMR $(300 \mathrm{MHz}$, $\left.\mathrm{CDCl}_{3}\right): 0.90(3 \mathrm{H}, \mathrm{t}, J=7.2 \mathrm{~Hz}), 1.86(1 \mathrm{H}, \mathrm{br} \mathrm{s}), 2.18-2.51(6 \mathrm{H}, \mathrm{m}), 3.04-3.09(1 \mathrm{H}, \mathrm{m}), 3.71$ and $3.79(2 \mathrm{H}, 2 \times \mathrm{d}, J=13.2 \mathrm{~Hz}), 4.19(1 \mathrm{H}, \mathrm{d} \times \mathrm{d}, J=13.9,5.0 \mathrm{~Hz}), 4.24(1 \mathrm{H}, \mathrm{d} \times \mathrm{d}, J=$ 13.9, $4.7 \mathrm{~Hz}), 5.59\left(2 \mathrm{H}\right.$, br s), 7.23-7.33 $(5 \mathrm{H}, \mathrm{m}), 7.96$ and $8.37(2 \mathrm{H}, 2 \times \mathrm{s}) .{ }^{13} \mathrm{C} \mathrm{NMR}(75$ $\left.\mathrm{MHz}, \mathrm{CDCl}_{3}\right): \delta 11.7,45.7,46.9,52.1,54.7,55.4,119.6,127.0,128.1,128.4,140.2,142.0$, 150.3, 152.9, 155.3. IR (ATR, $\left.\mathrm{cm}^{-1}\right): v_{N H}=3286,3228,3130 . \mathrm{MS}(70 \mathrm{eV}): \mathrm{m} / z(\%): 354\left(\mathrm{M}^{+}\right.$ $+1,100)$. Anal. calcd for $\mathrm{C}_{19} \mathrm{H}_{27} \mathrm{~N}_{7}: \mathrm{C} 64.56, \mathrm{H} 7.70, \mathrm{~N} 27.74$; found: $\mathrm{C} 64.83, \mathrm{H} 7.85, \mathrm{~N}$ 27.49 .

1-(6-Aminopurin-9-yl)-2-[(4-chlorophenyl)methyl]amino-3-diethylaminopropane (3b). Recrystallization from $\mathrm{CH}_{2} \mathrm{Cl}_{2} / \mathrm{Et}_{2} \mathrm{O}$ (4/1); yield $18 \%$; mp $=135.5{ }^{\circ} \mathrm{C} .{ }^{1} \mathrm{H} \mathrm{NMR}(300 \mathrm{MHz}$, $\left.\mathrm{CDCl}_{3}\right): 0.92(6 \mathrm{H}, \mathrm{t}, J=7.2 \mathrm{~Hz}), 1.80(1 \mathrm{H}, \mathrm{br} \mathrm{s}), 2.21-2.52(6 \mathrm{H}, \mathrm{m}), 3.01-3.09(1 \mathrm{H}, \mathrm{m}), 3.68$ and $3.75(2 \mathrm{H}, 2 \times \mathrm{d}, J=13.5 \mathrm{~Hz}), 4.17(1 \mathrm{H}, \mathrm{d} \times \mathrm{d}, J=14.1,5.3 \mathrm{~Hz}), 4.23(1 \mathrm{H}, \mathrm{d} \times \mathrm{d}, J=$ 14.1, 4.7 Hz), 5.61 (2H, br s), 7.15-7.18 and 7.23-7.25 (4H, $2 \times \mathrm{m}), 7.93$ and 8.37 (2H, $2 \times \mathrm{s})$. ${ }^{13} \mathrm{C}$ NMR $\left(75 \mathrm{MHz}, \mathrm{CDCl}_{3}\right): \delta 11.7,45.9,47.0,51.4,54.6,55.4,119.4,128.5,129.4,132.7$, 138.6, 141.8, 150.6, 152.9, 155.4. IR (ATR, $\left.\mathrm{cm}^{-1}\right): v_{N H}=3284$ and 3132. MS $(70 \mathrm{eV}): \mathrm{m} / \mathrm{z}$ (\%): 388/90 ( $\left.\mathrm{M}^{+}+1,100\right)$. Anal. calcd for $\mathrm{C}_{19} \mathrm{H}_{26} \mathrm{ClN}_{7}$ : C 58.83, H 6.67, N 25.28; found: $\mathrm{C}$ 58.72, H 7.14, N 24.96.

1-(6-Aminopurin-9-yl)-3-diethylamino-2-[(4-methoxyphenyl)methyl]aminopropane (3c). Recrystallization from $\mathrm{CH}_{2} \mathrm{Cl}_{2} / \mathrm{Et}_{2} \mathrm{O}$ (4/1); yield $13 \%$; mp $=106.8{ }^{\circ} \mathrm{C}$. ${ }^{1} \mathrm{H}$ NMR $(300 \mathrm{MHz}$, $\left.\mathrm{CDCl}_{3}\right): 0.91(3 \mathrm{H}, \mathrm{t}, J=7.2 \mathrm{~Hz}), 2.20-2.52(6 \mathrm{H}, \mathrm{m}), 3.03-3.11(1 \mathrm{H}, \mathrm{m}), 3.65$ and $3.73(2 \mathrm{H}, 2$ $\times \mathrm{d}, J=13.2 \mathrm{~Hz}), 3.79(3 \mathrm{H}, \mathrm{s}) ; 4.19(1 \mathrm{H}, \mathrm{d} \times \mathrm{d}, J=14.5,5.2 \mathrm{~Hz}), 4.23(1 \mathrm{H}, \mathrm{d} \times \mathrm{d}, J=14.5$, $4.4 \mathrm{~Hz}), 5.85\left(2 \mathrm{H}\right.$, br s), 6.81-6.85 (2H, m), 7.14-7.18 $(2 \mathrm{H}, \mathrm{m}), 7.97$ and $8.37(2 \mathrm{H}, 2 \times \mathrm{s}) .{ }^{13} \mathrm{C}$ NMR (75 MHz, $\left.\mathrm{CDCl}_{3}\right): \delta 11.7,45.8,46.9,51.5,54.5,55.3,55.4,113.8,129.3,119.3,132.2$, 141.9, 150.6, 152.9, 155.4, 158.7. IR (ATR, $\left.\mathrm{cm}^{-1}\right): v_{N H}=3322$ and 3159. MS $(70 \mathrm{eV}): \mathrm{m} / \mathrm{z}$ (\%): $384\left(\mathrm{M}^{+}+1,100\right)$. Anal. calcd for $\mathrm{C}_{20} \mathrm{H}_{29} \mathrm{~N}_{7} \mathrm{O}$ : C 62.64, H 7.62, N 25.57; found: $\mathrm{C}$ 62.38; H 7.74; N 25.41 . 
Synthesis of 2-(arylmethyl)amino-3-diethylamino-1-(2,4-dioxo-5-methylpyrimidin-1yl)propanes (3d-e). The procedure for the synthesis of compounds 3a-c was applied for the preparation of 2-(arylmethyl)amino-3-diethylamino-1-(2,4-dioxo-5-methylpyrimidin-1yl)propanes 3d-e. The crude products 3d-e were purified by column chromatography on aluminum oxide or by recrystallization.

2-[(4-Chlorophenyl)methyl]amino-3-diethylamino-1-(2,4-dioxo-5-methylpyrimidin-1-yl)propane 3d. Recrystallization from $\mathrm{CH}_{2} \mathrm{Cl}_{2} / \mathrm{Et}_{2} \mathrm{O}$ (4/1); yield $18 \%$; $\mathrm{mp}=42.1{ }^{\circ} \mathrm{C}$. ${ }^{1} \mathrm{H} \mathrm{NMR}$ (300 MHz, $\left.\mathrm{CDCl}_{3}\right): 0.95(3 \mathrm{H}, \mathrm{t}, J=6.9 \mathrm{~Hz}), 1.90(3 \mathrm{H}, \mathrm{s}), 2.30-2.54(6 \mathrm{H}, \mathrm{m}), 2.89-2.94(1 \mathrm{H}$, m), 3.63-3.77 (4H, m), $7.10(1 \mathrm{H}, \mathrm{s}), 7.19-7.29(4 \mathrm{H}, \mathrm{m}), 8.86(1 \mathrm{H}, \mathrm{br} \mathrm{s}) .{ }^{13} \mathrm{C}$ NMR $(75 \mathrm{MHz}$, $\left.\mathrm{CDCl}_{3}\right): \delta 11.8,12.2,47.0,50.9,51.5,54.2,55.3,109.6,128.6,129.4,132.8,138.8,142.2$, 151.2, 164.2. IR (ATR, $\left.\mathrm{cm}^{-1}\right): v_{C O}=1706$ and 1660, $v_{N H}=3248$. MS $(70 \mathrm{eV}): \mathrm{m} / z(\%): 379 / 81$ $\left(\mathrm{M}^{+}+1,100\right)$. Anal. calcd for $\mathrm{C}_{19} \mathrm{H}_{27} \mathrm{ClN}_{4} \mathrm{O}_{2}: \mathrm{C} 60.23, \mathrm{H} 7.18, \mathrm{~N} 14.79$; found: $\mathrm{C} 60.55, \mathrm{H}$ 7.42, N 14.57 .

\section{3-Diethylamino-1-(2,4-dioxo-5-methylpyrimidin-1-yl)-2-[(4-methoxyphenyl)methyl]-}

aminopropane 3e. $R_{\mathrm{f}}=0.08\left(\mathrm{CH}_{2} \mathrm{Cl}_{2} / \mathrm{MeOH}\right)$; yield 65\%. ${ }^{1} \mathrm{H} \mathrm{NMR}\left(300 \mathrm{MHz}, \mathrm{CDCl}_{3}\right): 0.94$ $(3 \mathrm{H}, \mathrm{t}, J=7.2 \mathrm{~Hz}), 1.90(3 \mathrm{H}, \mathrm{s}), 2.32-2.53(6 \mathrm{H}, \mathrm{m}), 2.90-2.98(1 \mathrm{H}, \mathrm{m}), 3.65-3.74(4 \mathrm{H}, \mathrm{m})$, $3.77(3 \mathrm{H}, \mathrm{s}), 7.13(1 \mathrm{H}, \mathrm{s}), 6.82-6.85(2 \mathrm{H}, \mathrm{m}), 7.13(1 \mathrm{H}, \mathrm{s}), 7.17-7.20(2 \mathrm{H}, \mathrm{m}) .{ }^{13} \mathrm{C}$ NMR $(75$ $\left.\mathrm{MHz}, \mathrm{CDCl}_{3}\right): \delta 11.7,12.3,46.9,50.9,51.5,53.8,55.2,55.3,109.5,113.8,129.4,132.3$, 142.2, 151.7, 158.6, 165.0. IR (ATR, $\left.\mathrm{cm}^{-1}\right): v_{C O}=1674, v_{N H}=3172$ and 3029. MS (70eV): $m / z(\%): 375\left(\mathrm{M}^{+}+1,100\right)$. Anal. calcd for $\mathrm{C}_{20} \mathrm{H}_{30} \mathrm{~N}_{4} \mathrm{O}_{3}$ : C 64.15, H 8.07, N 14.96; found: $\mathrm{C}$ 63.97, H 8.21, N 14.82 .

Synthesis of 2-(arylmethyl)amino-3-diethylamino-1-(1,2,4-triazol-1-yl)propanes (3f-h). The procedure for the synthesis of compounds 3a-c was applied for the preparation of 2(arylmethyl)amino-3-diethylamino-1-(1,2,4-triazol-1-yl)propanes 3f-h. The crude products 3f-h were purified by column chromatography on aluminum oxide $\left(\mathrm{CH}_{2} \mathrm{Cl}_{2} / \mathrm{MeOH} 99 / 1\right)$.

3-Diethylamino-2-(phenylmethyl)amino-1-(1,2,4-triazol-1-yl)propane $\quad 3 f . \quad R_{\mathrm{f}}=0.54$ $\left(\mathrm{CH}_{2} \mathrm{Cl}_{2} / \mathrm{MeOH} 99 / 1\right)$; yield 40\%. ${ }^{1} \mathrm{H}$ NMR (300 MHz, $\left.\mathrm{CDCl}_{3}\right): 0.91(6 \mathrm{H}, \mathrm{t}, J=6.9 \mathrm{~Hz}), 2.27$ $(1 \mathrm{H}, \mathrm{d} \times \mathrm{d}, J=14.2,6.3 \mathrm{~Hz}), 2.30(1 \mathrm{H}, \mathrm{d} \times \mathrm{d}, J=14.2,8.3 \mathrm{~Hz}), 2.34-2.48(4 \mathrm{H}, \mathrm{m}), 3.00-3.08$ $(1 \mathrm{H}, \mathrm{m}), 3.64$ and $3.69(2 \mathrm{H}, 2 \times \mathrm{d}, J=13.5 \mathrm{~Hz}), 4.12(1 \mathrm{H}, \mathrm{d} \times \mathrm{d}, J=14.0,5.2 \mathrm{~Hz}), 4.21(1 \mathrm{H}$, $\mathrm{d} \times \mathrm{d}, J=14.0,4.7 \mathrm{~Hz}), 7.20-7.36(5 \mathrm{H}, \mathrm{m}), 7.93$ and $8.13(2 \mathrm{H}, 2 \times \mathrm{s}) .{ }^{13} \mathrm{C} \mathrm{NMR}(75 \mathrm{MHz}$, $\left.\mathrm{CDCl}_{3}\right): \delta 11.7,46.9,51.9,52.0,54.6,55.2,127.0,128.1,140.1,144.1,151.6$. IR (ATR, $\mathrm{cm}^{-}$ $\left.{ }^{1}\right): v_{N H}=3300$. MS $(70 \mathrm{eV}): \mathrm{m} / z(\%): 288\left(\mathrm{M}^{+}+1,100\right)$. Anal. calcd for $\mathrm{C}_{16} \mathrm{H}_{25} \mathrm{~N}_{5}: \mathrm{C} 66.86, \mathrm{H}$ 8.77, N 24.37; found: C 66.94, H 8.95, N 24.42. 
2-[(4-Chlorophenyl)methyl]amino-3-diethylamino-1-(1,2,4-triazol-1-yl)propane 3g. $R_{\mathrm{f}}=$ $0.12\left(\mathrm{CH}_{2} \mathrm{Cl}_{2} / \mathrm{MeOH} 99 / 1\right)$; yield 31\%. ${ }^{1} \mathrm{H} \mathrm{NMR}\left(300 \mathrm{MHz}, \mathrm{CDCl}_{3}\right): 0.93(6 \mathrm{H}, \mathrm{t}, J=7.2 \mathrm{~Hz}$, ), $2.27(1 \mathrm{H}, \mathrm{d} \times \mathrm{d}, J=12.8,6.3 \mathrm{~Hz}), 2.31(1 \mathrm{H}, \mathrm{d} \times \mathrm{d}, J=12.8,8.3 \mathrm{~Hz}), 2.33-2.53(4 \mathrm{H}, \mathrm{m})$, 3.00-3.08 (1H, m), 3.60 and $3.64(2 \mathrm{H}, 2 \times \mathrm{d}, J=13.5 \mathrm{~Hz}), 4.13(1 \mathrm{H}, \mathrm{d} \times \mathrm{d}, J=13.9,5.8 \mathrm{~Hz})$, $4.23(1 \mathrm{H}, \mathrm{d} \times \mathrm{d}, J=13.9,4.4 \mathrm{~Hz}), 7.16-7.23$ and 7.26-7.29 $(4 \mathrm{H}, 2 \times \mathrm{m}), 7.94$ and $8.14(2 \mathrm{H}, 2$ $\times \mathrm{s}) .{ }^{13} \mathrm{C} \mathrm{NMR}\left(75 \mathrm{MHz}, \mathrm{CDCl}_{3}\right): \delta 11.7,47.0,51.3,52.0,54.6$ 55.2, 128.5,129.4, 132.7, 138.6, 144.1, 151.7. IR (ATR, $\left.\mathrm{cm}^{-1}\right): v_{N H}=3290$. MS $(70 \mathrm{eV}): \mathrm{m} / z(\%): 322 / 4\left(\mathrm{M}^{+}+1,100\right)$. Anal. calcd for $\mathrm{C}_{16} \mathrm{H}_{24} \mathrm{ClN}_{5}$ : C 59.71, H 7.52, N 21.76; found: C 59.83, H 7.68, N 21.74.

3-Diethylamino-2-[(4-methoxyphenyl)methyl]amino-1-(1,2,4-triazol-1-yl)propane $3 \mathrm{~h}$. $R_{\mathrm{f}}$ $=0.20\left(\mathrm{CH}_{2} \mathrm{Cl}_{2} / \mathrm{MeOH} 99 / 1\right)$; yield $19 \% .{ }^{1} \mathrm{H} \mathrm{NMR}\left(300 \mathrm{MHz}, \mathrm{CDCl}_{3}\right): 0.93(6 \mathrm{H}, \mathrm{t}, J=7.2$ $\mathrm{Hz}), 2.29-2.32(2 \mathrm{H}, \mathrm{m}), 2.35-2.50(4 \mathrm{H}, \mathrm{m}), 3.04-3.06(1 \mathrm{H}, \mathrm{m}), 3.59$ and $3.64(2 \mathrm{H}, 2 \times \mathrm{d}, J=$ $12.7 \mathrm{~Hz}), 3.80(3 \mathrm{H}, \mathrm{s}), 4.11-4.26(2 \mathrm{H}, \mathrm{m}), 6.84-6.87(2 \mathrm{H}, \mathrm{m}), 7.16-7.19(2 \mathrm{H}, \mathrm{m}), 7.95$ and $8.16(2 \mathrm{H}, 2 \times \mathrm{s}) .{ }^{13} \mathrm{C} \mathrm{NMR}\left(75 \mathrm{MHz}, \mathrm{CDCl}_{3}\right): \delta 11.6,46.9,51.5,52.0,54.5,55.2,55.3,113.9$, 129.3, 132.1, 144.2, 151.7, 158.7. IR (ATR, $\left.\mathrm{cm}^{-1}\right): v_{N H}=3311 . \mathrm{MS}(70 \mathrm{eV}): \mathrm{m} / z(\%): 318\left(\mathrm{M}^{+}\right.$ $+1,100)$. Anal. calcd for $\mathrm{C}_{17} \mathrm{H}_{27} \mathrm{~N}_{5} \mathrm{O}: \mathrm{C} 64.32, \mathrm{H} 8.57, \mathrm{~N} 22.06$; found: $\mathrm{C} 64.45, \mathrm{H} 8.73, \mathrm{~N}$ 12.89 .

Synthesis of 2-(arylmethyl)amino-1,3-bis(diethylamino)propanes (3i-k). The procedure for the synthesis of compounds 3a-c was applied for the preparation of 2-(arylmethyl)amino1,3-bis(diethylamino)propanes $\mathbf{3 i - k}$. The crude products $\mathbf{3 i - k}$ were purified by column chromatography on aluminum oxide $\left(\mathrm{CH}_{2} \mathrm{Cl}_{2} / \mathrm{MeOH} 99 / 1\right)$.

1,3-Bis(diethylamino)-2-(phenylmethyl)aminopropane 3i. $R_{\mathrm{f}}=0.10\left(\mathrm{CH}_{2} \mathrm{Cl}_{2} / \mathrm{MeOH} 99 / 1\right)$; yield $31 \%$. ${ }^{1} \mathrm{H}$ NMR (300 MHz, $\left.\mathrm{CDCl}_{3}\right): 0.98(12 \mathrm{H}, \mathrm{t}, J=7.2 \mathrm{~Hz}), 2.39-2.53(12 \mathrm{H}, \mathrm{m}), 2.66-$ $2.74(1 \mathrm{H}, \mathrm{m}), 3.87(2 \mathrm{H}, \mathrm{s}), 7.28-7.34(5 \mathrm{H}, \mathrm{m}) .{ }^{13} \mathrm{C} \mathrm{NMR}\left(75 \mathrm{MHz}, \mathrm{CDCl}_{3}\right): \delta$ 12.0, 47.6, 52.0, 52.7, 57.1, 126.9, 128.4, 128.5, 140.8. IR (ATR, $\left.\mathrm{cm}^{-1}\right): v_{N H}=3295 . \mathrm{MS}(70 \mathrm{eV}): \mathrm{m} / \mathrm{z}(\%): 292$ $\left(\mathrm{M}^{+}+1,100\right)$. Anal. calcd for $\mathrm{C}_{18} \mathrm{H}_{33} \mathrm{~N}_{3}$ : C 74.14, H 11.41, $\mathrm{N}$ 14.42; found: C 74.03, H 11.36, N 14.30.

2-[(4-Chlorophenyl)methyl]amino-1,3-bis(diethylamino)propane $\quad 3 j . \quad R_{\mathrm{f}}=0.16$ $\left(\mathrm{CH}_{2} \mathrm{Cl}_{2} / \mathrm{MeOH} 99 / 1\right)$; yield 25\%. ${ }^{1} \mathrm{H}$ NMR (300 MHz, $\left.\mathrm{CDCl}_{3}\right): 0.98(12 \mathrm{H}, \mathrm{t}, J=7.2 \mathrm{~Hz})$, 2.37-2.55 (12H, m), 2.59-2.71 (1H, m), $3.83(2 \mathrm{H}, \mathrm{s}), 7.18-7.29(4 \mathrm{H}, \mathrm{m}) .{ }^{13} \mathrm{C}$ NMR $(75 \mathrm{MHz}$, $\left.\mathrm{CDCl}_{3}\right): \delta 11.9,47.5,51.3,52.7,57.1,128.4,129.5,132.4,139.5 . \mathrm{IR}\left(\mathrm{ATR}, \mathrm{cm}^{-1}\right): v_{N H}=$ 3288. MS (70 eV): $\mathrm{m} / \mathrm{z}(\%): 326 / 8\left(\mathrm{M}^{+}+1,100\right)$. Anal. calcd for $\mathrm{C}_{18} \mathrm{H}_{32} \mathrm{ClN}_{3}: \mathrm{C} 66.33, \mathrm{H}$ 9.90, N 12.89; found: C 66.57, H 10.13, N 12.77. 
1,3-Bis(diethylamino)-2-[(4-methoxyphenyl)methyl]aminopropane $\quad 3 \mathrm{k} . \quad R_{\mathrm{f}}=0.19$ $\left(\mathrm{CH}_{2} \mathrm{Cl}_{2} / \mathrm{MeOH} 99 / 1\right)$; yield 13\%. ${ }^{1} \mathrm{H}$ NMR $\left(300 \mathrm{MHz}, \mathrm{CDCl}_{3}\right): 1.00(12 \mathrm{H}, \mathrm{t}, J=7.2 \mathrm{~Hz})$, 2.41-2.58 (12H, m), 2.64-2.81 (1H, m), $3.80(3 \mathrm{H}, \mathrm{s}), 3.90(2 \mathrm{H}, \mathrm{s}), 6.86-6.89(2 \mathrm{H}, \mathrm{m}), 7.25-$ $7.31(2 \mathrm{H}, \mathrm{m}) .{ }^{13} \mathrm{C}$ NMR $\left(75 \mathrm{MHz}, \mathrm{CDCl}_{3}\right): \delta 11.6,47.3,50.5,52.2,55.3,56.3,113.9,129.7$, 130.3, 158.8. IR $\left(\mathrm{ATR}, \mathrm{cm}^{-1}\right): v_{N H}=3298$. MS $(70 \mathrm{eV}): \mathrm{m} / \mathrm{z}(\%): 322\left(\mathrm{M}^{+}+1,100\right)$. Anal. calcd for $\mathrm{C}_{19} \mathrm{H}_{35} \mathrm{~N}_{3} \mathrm{O}$ : C 70.98, H 10.97, N 13.07; found: C 71.18, H 11.07, N 13.00.

\section{Acknowledgements}

The authors are indebted to the "Institute for the Promotion of Innovation through Science and Technology - Flanders" (IWT-Vlaanderen), to the "Fund for Scientific Research Flanders" (FWO-Vlaanderen) and to Ghent University (GOA) for financial support.

\section{References}

[1] WHO Fact sheet on malaria $\mathrm{N}^{\circ} 94$, January 2009.

[2] P. M. S. Chauhan, S. K. Srivastava, Curr. Med. Chem. 8 (2001) 1535-1542.

[3] C. W. Jefford, Curr. Med. Chem. 8 (2001) 1803-1826.

[4] T. R. Sweeney, Med. Res. Rev. 1 (1981) 281-301.

[5] A. Kumar, S. B. Katiyar, A. Agarwal, P. M. S. Chauhan, Curr. Med. Chem. 10 (2003) 1137-1150.

[6] L. J. Bruce-Chwatt, R. H. Black, C. J. Canfield, D. F. Clyde, W. Peters, W. H. Wernsdorfer (Eds.) Chemotherapy of Malaria. 2nd ed., WHO, Geneva, 1986.

[7] A. Robin, F. Brown, N. Bahamontes-Rosa, B. Wu, E. Beitz, J. F. J. Kun, S. L. Flitsch, J. Med. Chem. 50 (2007) 4243-4249.

[8] M. D'hooghe, S. Dekeukeleire, K. Mollet, C. Lategan, P. J. Smith, K. Chibale, N. De Kimpe, J. Med. Chem. 52 (2009) 4058-4062.

[9] S. Pérez-Silanes, L. Berrade, R. N. García-Sánchez, A. Mendoza, S. Galiano, B. M. Pérez-Solórzano, J. J. Nogal-Ruiz, A. R. Martínez-Fernández, I. Aldana, A. Monge, Molecules 14 (2009) 4120-4135.

[10] B. Zwanenburg, P. ten Holte, Top. Curr. Chem. 216 (2001) 93-124. (b) (c) (d) (e) (f) (g) (h) (i)

[11] J. B. Sweeney, Chem. Soc. Rev. 31 (2002) 247-258. 
[12] X. E. Hu, Tetrahedron 60 (2004) 2701-2743.

[13] D. Tanner, Angew. Chem. Int. Ed. 33 (1994) 599-619.

[14] W. M. McCoull, F. A. Davis, Synthesis (2000) 1347-1365.

[15] I. D. G. Watson, L. Yu, A. K. Yudin, Acc. Chem. Res. 39 (2006) 194-206.

[16] A. Padwa, S. S. Murphree, Arkivoc (iii) (2006) 6-33.

[17] G. S. Singh, M. D’hooghe, N. De Kimpe, Chem. Rev. 107 (2007), 2080-2135.

[18] T. N. Wade. J. Org. Chem. 45 (1980) 5328-5333.

[19] D. Gnecco, L. Orea, F. A. Galindo, R. G. Enríquez, R. A. Toscano, W. F. Reynolds, Molecules 5 (2000) 998-1003.

[20] P. O’Brien, T. D. Towers, J. Org. Chem. 67 (2002) 304-307.

[21] T. B. Sim, S. H. Kang, K. S. Lee, W. K. Lee, H. Yun, Y. Dong, H.-J. Ha, J. Org. Chem. 68 (2003) 104-108.

[22] M. D’hooghe, V. Van Speybroeck, M. Waroquier, N. De Kimpe, Chem. Commun. (2006) 1554-1556.

[23] M. D’hooghe, K. Vervisch, A. Van Nieuwenhove, N. De Kimpe, Tetrahedron Lett. 48 (2007) 1771-1774.

[24] M. D’hooghe, V. Van Speybroeck, A. Van Nieuwenhove, M. Waroquier, N. De Kimpe, J. Org. Chem. 72 (2007) 4733-4740.

[25] Y. Kim, H.-J. Ha, S. Y. Yoon, W. K. Lee, Chem. Commun. (2008) 4363-4365.

[26] M. D’hooghe, W. Aelterman, N. De Kimpe, Org. Biomol. Chem. 7 (2009) 135-141.

[27] S. Y. Yun, S. Catak, W. K. Lee, M. D’hooghe, N. De Kimpe, V. Van Speybroeck, M. Waroquier, Y. Kim, H.-J. Ha, Chem. Commun. (2009) 2508-2510.

[28] H. A. Song, M. Dadwal, Y. Lee, E. Mick, H. S. Chong, Angew. Chem. Int. Ed. 48 (2009) $1328-1330$.

[29] T. X. Metro, B. Duthion, D. G. Pardo, J. Cossy, Chem. Soc. Rev. (2010) 89-102.

[30] S. Catak, M. D’hooghe, N. De Kimpe, M. Waroquier, V. Van Speybroeck, J. Org. Chem. 75 (2010) 885-896.

[31] H. S. Chong, H. A. Song, M. Dadwal, X. Sun, I. Sin, Y. W. Chen, J. Org. Chem. 75 (2010) 219-221.

[32] M. D'hooghe, N. De Kimpe, Arkivoc (x) (2007) 365-373.

[33] M. D'hooghe, N. De Kimpe, Arkivoc (ix) (2008) 6-19.

[34] M. D'hooghe, N. De Kimpe, Chem. Commun. (2007) 1275-1277.

[35] M. Karikomi, N. De Kimpe, Tetrahedron Lett. 41 (2000) 10295-10298. 
[36] J. L. Pierre, P. Baret, Comptes Rendus 272 (1971) 2069-2072.

[37] V. R. Gaertner, J. Heterocyclic Chem. 8 (1971) 177-178.

[38] V. R. Gaertner, J. Org. Chem. 35 (1970) 3952-3959.

[39] G. Szeimies, Chem. Ber. 106 (1973) 3695-3724.

[40] P. M. O'Neill, P. G. Bray, S. R. Hawley, S. A. Ward, B. K. Park, Pharmacol Ther. 77 (1998) 29-58.

[41] N. De Kimpe, R. Jolie, D. De Smaele, J. Chem. Soc. Chem. Commun. (1994) 12211222 .

[42] M. D’hooghe, A. Waterinckx, N. De Kimpe, J. Org. Chem. 70 (2005) 227-232.

[43] M. D’hooghe, M. Rottiers, R. Jolie, N. De Kimpe, Synlett (2005) 931-934.

[44] L. Harmse, R. van Zyl, N. Gray, P. Schultz, S. Leclerc, L. Meijer, C. Doerig, I. Havlik, Biochem. Pharmacol. 62 (2001) 341-348.

[45] G. Abu Sheikha, P. La Colla, A. G. Loi, Nucleosides, Nucleotides \& Nucleic Acids 21 (2002) 619-653.

[46] M. Legraverend, D. S. Grierson, Bioorg. Med. Chem. 14 (2006) 3987-4006.

[47] M. Legraverend, Tetrahedron 64 (2008) 8585-8603.

[48] V. Ralevic, G. Burnstock, Pharmacol. Rev. 50 (1998) 413-492.

[49] B. Tarnchompoo, C. Sirichaiwat, W. Phupong, C. Intaraudom, W. Sirawaraporn, S. Kamchonwongpaisan, J. Vanichtanankul, Y. Thebtaranonth, Y. J. Yuthavong, J. Med. Chem. 45 (2002) 1244-1252.

[50] C. Sirichaiwat, C. Intaraudom, S. Kamchonwongpaisan, J. Vanichtanankul, Y. Thebtaranonth, Y. Yuthavong, J. Med Chem. 47 (2004) 345-354.

[51] Y. Chen, M. Lopez-Sanchez, D. N. Savoy, D. D. Billadeau, G. S. Dow, A. P. Kozikowski, J. Med. Chem. 51 (2008) 3437-3448.

[52] W. Trager, J. B. Jensen, Science 193 (1976) 673-675.

[53] M. T. Makler, J. M. Ries, J. A. Williams, J. E. Bancroft, R. C. Piper, B. L. Gibbins, D. Hinrichs, J. Am. J. Trop. Med. Hyg. 48 (1993) 739-741. Test samples were tested at a starting concentration of $100 \mu \mathrm{g} / \mathrm{mL}$, which was then serially diluted two-fold in complete medium to give 10 concentrations; with the lowest concentration being $0.2 \mu \mathrm{g} / \mathrm{mL}$. The same dilution technique was used for all samples. CQ was tested at a starting concentration of $100 \mathrm{ng} / \mathrm{mL}$. The highest concentration of solvent to which the parasites were exposed to had no measurable effect on the parasite viability. The IC50-values were obtained using a non-linear dose-response curve fitting analysis via Graph Pad Prism v.4.0 software. 
[54] T. Mosmann, J. Immunol. Methods 65 (1983) 55-63. The initial concentration of emetine was $100 \mu \mathrm{g} / \mathrm{mL}$, which was serially diluted in complete medium with ten-fold dilutions to give 6 concentrations, the lowest being $0.001 \mu \mathrm{g} / \mathrm{mL}$. The same dilution technique was applied to all the test samples. The highest concentration of solvent to which the cells were exposed to had no measurable effect on the cell viability (data not shown). The IC50-values were obtained from full dose-response curves, using a non-linear dose-response curve fitting analysis via GraphPad Prism v.4 software.

[55] L. V. Rubinstein, R. H. Shoemaker, K. D. Paull, R. M. Simon, S. Tosini, P. Skehan, D. A. Scudiero, A. Monks, M. R. Boyd, J. Natl. Cancer Inst. 82 (1990) 1113-1118. 